\title{
Gorlin syndrome
}

\author{
Jane E Hooper, ${ }^{1}$ Jonathan Schofield, ${ }^{1}$ Handrean Soran, ${ }^{1,2}$ Richard W Whitehouse ${ }^{3}$
}

'Department of Medicine, Manchester Royal Infirmary, Manchester, UK

${ }^{2}$ University of Manchester, Manchester, UK

${ }^{3}$ Department of Radiology, Manchester Royal Infirmary, Manchester, UK

\section{Correspondence to} Dr Jane E Hooper, janehooper@nhs.net

\section{CrossMark}

To cite: Hooper JE, Schofield J, Soran $\mathrm{H}$, et al. BMJ Case Rep Published online: [please include Day Month Year] doi:10.1136/ bcr-2013-201045

\section{DESCRIPTION}

An asymptomatic 56-year-old woman with a history of multiple basal cell carcinomas (BCCs) and odontogenic keratocysts was referred to the metabolic clinic for assessment of bone density. On examination, there were no plantar or palmar pits, facial abnormalities or macrocephaly and the family history was also unremarkable. Osteoporosis was excluded, but plain films showed multiple cysts throughout the long bones (figure 1) and subsequent abdominal CT revealed multiple large mesenteric cysts (figure 2). Multiplex ligation-dependent probe amplification analysis confirmed a heterozygous pathogenic deletion in patched 1 , consistent with a diagnosis of Gorlin syndrome.

Gorlin syndrome, or naevoid BCC syndrome, is a rare autosomal dominant condition of variable expression, which has an estimated prevalence of 1 in 164000 in the UK. ${ }^{1}$

Gorlin syndrome can present with a wide range of multisystem manifestations. Clinical features include the early onset BCCs, macrocephaly, palmar or plantar pits and coarse facies. Common radiological findings include benign keratocystic odontogenic tumours of the jaw, rib abnormalities and early calcification of the falx cerebri. ${ }^{2}$ The radiological features in this case have been described less frequently, with polyostotic bone

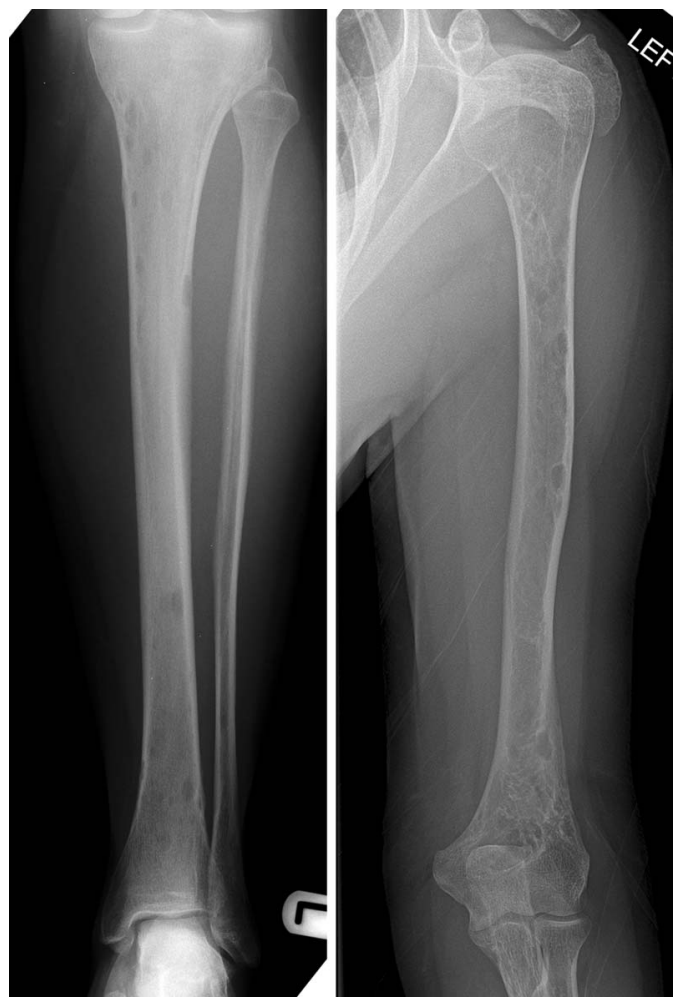

Figure 1 Plain X-rays showing diffuse long bone cysts.
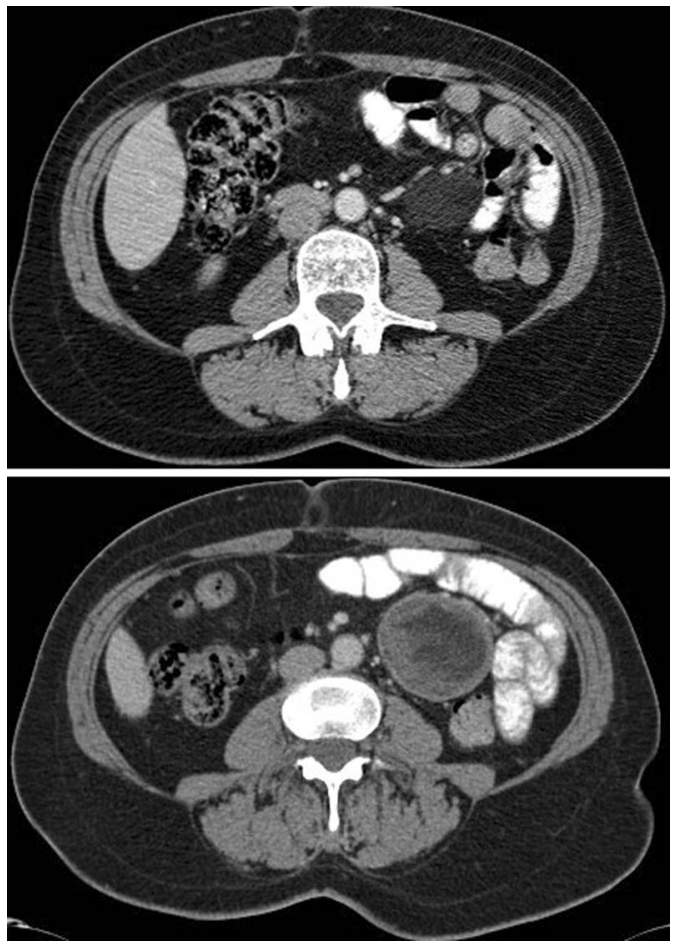

Figure 2 CT scan showing a large mesenteric cyst.

cysts being present in less than 50\% and lymphomesenteric cysts in less than 5\% of individuals with Gorlin syndrome. ${ }^{3}$

Examples of common radiological findings have been widely published, but these striking images demonstrating large bone cysts with diffuse axial involvement and lymphomesenteric cysts are unusual even in this rare disease.

\section{Learning points}

Gorlin syndrome is a rare condition of great clinical importance due to the predisposition to benign and malignant tumours.

- The commonest features are early onset basal cell carcinomas, odontogenic keratocysts and early calcification of the falx cerebri.

- Although diagnosis is frequently established using clinical diagnostic criteria, PTCH1 is the only gene in which mutations are known to cause Gorlin syndrome.

Acknowledgements The authors would like to thank Dr Bill Newman for providing information on genetic testing and results. 
Contributors JEH and JS participated in the writing of the manuscript. HS contributed to identifying the case and to overseeing the overall content. RWW was involved in the identification and formatting of the images.

\section{Competing interests None.}

Patient consent Obtained.

Provenance and peer review Not commissioned; externally peer reviewed.

\section{REFERENCES}

1 Evans DG, Ladusans EJ, Rimmer $S$, et al. Complications of the naevoid basal cell carcinoma syndrome: results of a population based study. J Med Genet 1993;30:460-4.

2 Pagon RA, Adam MP, Bird TD, et al. Nevoid basal cell carcinoma syndrome. Gene Rev 2002 [Updated 2013 Mar 7]; 1993-2013.

3 Mitchell G, Farndon PA, Brayden P, et al. Genetic predisposition to cancer: the consequences of a delayed diagnosis of Gorlin syndrome. Clin Oncol (R Coll Radiol) 2005;17:650-4.

Copyright 2013 BMJ Publishing Group. All rights reserved. For permission to reuse any of this content visit http://group.bmj.com/group/rights-licensing/permissions.

BMJ Case Report Fellows may re-use this article for personal use and teaching without any further permission.

Become a Fellow of BMJ Case Reports today and you can:

- Submit as many cases as you like

- Enjoy fast sympathetic peer review and rapid publication of accepted articles

- Access all the published articles

- Re-use any of the published material for personal use and teaching without further permission

For information on Institutional Fellowships contact consortiasales@bmjgroup.com

Visit casereports.bmj.com for more articles like this and to become a Fellow 